\section{New moon for Neptune}

\section{Washington}

Stx weeks away from its rendezvous with Neptune, the Voyager 2 spacecraft has discovered a third moon orbiting the planet. Neptune's other two moons are the almost Earth-sized Triton and the smaller Nereid. The new object was first seen three weeks ago as a bright spot moving against the background of stars, but no resolved image of it has yet been made. It is estimated to be between 125 and 400 miles in diameter, and is moving in an approximately circular, 60,000-mile-radius equatorial orbit. D.L.

\section{From moulds to money}

\section{London}

A SLIME-MOULD biochemist is to become the next director of the London School of Economics (LSE). But it is presumably for his other skills that Professor John Ashworth has landed the job. Currently vice-chancellor of the Universitv of

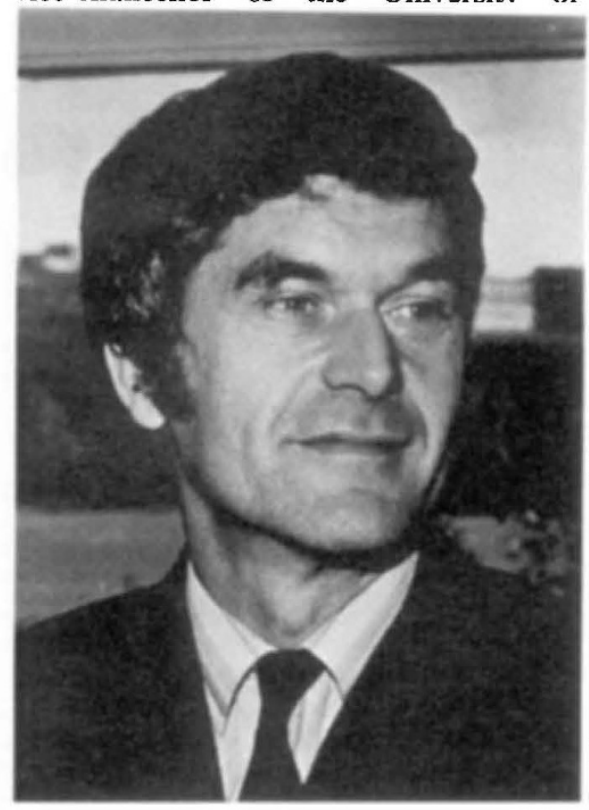

round by attracting an influx of industrial money, Ashworth served as chief scientist in the Central Policy Review Staff, the prime minister's 'think-tank', from 1976 to 1981 . He succeeds Dr Indraprasad Patel at LSE in October 1990.

P.N.

\section{Embezzlement arrest}

\section{London}

AN employee of the Chinese Academy of Sciences is under arrest in the biggest embezzlement case in the history of the Chinese People's Republic, it was announced last week. Shen Xiaoping, described as a purchasing agent of the academy's Microelectronics Centre, is alleged to have embezzled more than 390,000 yuan $(£ 115,000)$ of public money allocated to the centre between March 1985 and December 1987. In all, 12 people are involved in the case. Six are in custody, and the rest are on bail awaiting trial.

V.R.

\title{
The end of a scientific era?
}

\section{Munich}

THE glowing fifteen-year tradition of the Dahlem Conferences in West Berlin may be brought to an abrupt stop next year unless a new sponsor can be found. The current sponsor, the industry group "Donors Association for Promoting Arts and Sciences in West Germany" (Stifterverband für die Deutsche Wissenschaft or SV) plans to keep its longstanding promise to drop the conferences at the end of 1989.

The Dahlem conferences have been praised by participants for their unique structure. There are four conferences a year for 40 to 50 participants, by invitation only, on subjects ranging from neurosciences to global change. By contrast with the slide-projector and coffee-break routine of most scientific meetings, participants meet in small groups to discuss interdisciplinary topics. The result of each conference is a book, written while the discussion is still fresh.

Members of the scientific board of the conferences reacted with outrage at the revelation late last month that the staff of seven had been dismissed from December 1989. Jean-Pierre Changeux of the Pasteur Institute in France said it would be a "disaster" if the conferences were to end; Hubert Markl, president of the West German granting agency DFG (Deutsche Forschungsgemeinschaft) called the conferences "an invaluable instrument of international science promotion". DFG provides money for travel grants to the participants in one Dahlem conference a year.

SV had announced in 1986 its intention to transfer control of the conferences to some other agency. At first, the Wissenschaftskolleg (Institute for Advanced Studies) of West Berlin, the construction of which SV helped to finance, seemed prepared to take the reins, but talks broke down in 1986

The ill-fated Academy of Science and Technology in Berlin offered in 1987 to take over the conferences, but conference leader Silke Bernhard balked at the transfer. The academy plan had to be shelved in April this year when the newly elected Green-Social Democratic government in West Berlin announced its intention to shut down the Academy.

Bernhard, a physician with a strong background in science promotion, is given credit by many participants for the success of the meetings. She saw her autonomy, and with it the quality of the conferences, threatened by the intentions of the Academy. She was supported in her stand by other members of the scientific board, including Changeux and Sir Gordon Wolstenholme of the Royal College of Physicians in London, who have written stirring letters in her defence.

Bernhard charges that SV has decided to disband the conference organization now, instead of seeking a new sponsor, out of a desire for personal revenge against her and possibly for political reasons. There had been an earlier dispute, concerning publication of the Dahlem conference books, which led to bad blood between Bernhard and the SV general secretary, Horst Niemeyer, and the conference administrator, HansHenning Pistor.

Bernhard sees a political motive in the desire for SV to retaliate against the new West Berlin Senate for shutting down the Academy of Science and Technology. Although SV has no official political affiliation, it is thought to be in alignment with the conservative West German Christian Democratic party, which had shepherded the Berlin Academy into existence over the objections of the Social Democrats.

Pistor rejected vehemently Bernhard's charges of vengeance, saying it was beneath the dignity of SV to respond. $\mathrm{He}$ said that Bernhard is "an employee and she just has to accept that role. It was solely her refusal to accept the Academy's conditions" that led SV to carry out its plan to end the conferences.

As for the political motive, Pistor called the idea "foolish", saying that SV would "never even think of such an idea". Pistor, who has administered the conferences for SV since 1978 , said that "no-one plans" to shut down the conferences if it can be helped. The West Berlin Senate has proposed that the Free University of Berlin take over sponsorship, an idea that Pistor called "difficult" but which the university is still considering.

Another idea which might save the conferences is the setting up of an independent, registered organization, or Verein, to administer the conferences and take all legal responsibility. Pistor said that SV would not object to this proposed structure if appropriate board members could be found.

Ironically, money is not the largest problem in keeping the conferences running. The city of West Berlin has promised DM 1 million (about $\$ 500,000$ ) a year for five years toward operating costs, as long as a suitable sponsor is found. DFG, the multinational company Unilever and other sources provide most of the rest of the budget, leaving a shortfall of just DM 160,000

But time is running out for the conferences. Bernhard expects most of the staff to leave before the end of the year, even though two more conferences are scheduled in November and December. 